Черчик Лариса, доктор економічних наук, професор, Волинський національний університет імені Лесі Українки, завідувач кафедри менеджменту та адміністрування, м. Луцьк; ORCID ID: 0000-0002-3901-216X e-mail: cherchyk.larysa@ vnu.edu.ua

https://doi.org/10.29038/2786-4618-2021-01-135-141

\title{
ІНТЕГРОВАНІ СИСТЕМИ МЕНЕДЖМЕНТУ ЯК ІНСТРУМЕНТ ПОГЛИБЛЕННЯ СВРОІНТЕГРАЦІЙНИХ ПРОЦЕСІВ
}

У статті інтегровані системи менеджменту розглянуто як інструменти євроінтеграції та забезпечення збалансованого, гармонійного розвитку, досягнення позитивної стабільності, конкурентоспроможності та безпеки. Встановлено, що складність та багатогранність сучасних проблем вимагає формування нових інтегрованих систем менеджменту. Обгрунтовано, що основними перевагами застосування інтеграційного підходу над існуючими є можливість розгляду об’єктів як складних соціоекологоекономічних систем, а інтегровані системи менеджменту мають бути націлені на оптимізацію взаємозалежних економічних, соціальних, технологічних і природних процесів в єдиному середовищі. Запропоновано розглядати інтегровану систему менеджменту як динамічну соціально- та екологоорієнтовану модель регулювання суспільного розвитку, спрямовану на реалізацію принципів сталого розвитку, імплементованих у систему національних і міжнародних стандартів, конвенцій, правил та рекомендацій ЄС шляхом поєднання зусиль державних органів влади, органів місцевого самоврядування, інститутів громадянського суспільства, бізнесу.

Ключові слова: євроінтеграційні процеси, інтегровані системи менеджменту, сталий розвиток, міжнародні стандарти.

Черчик Лариса, доктор экономических наук, профессор, Волынский национальный университет имени Леси Украинки, заведующая кафедры менеджмента и администрирования, г. Луцк

\section{ИНТЕГРИРОВАННЫЕ СИСТЕМЫ МЕНЕДЖМЕНТА КАК ИНСТРУМЕНТ УГЛУБЛЕНИЯ ЕВРОИНТЕГРАЦИОННЫХ ПРОЦЕССОВ}

В статье интегрированные системы менеджмента рассмотрены как инструменты евроинтеграции и обеспечения сбалансированного, гармоничного развития, достижения положительной стабильности, конкурентоспособности и безопасности. Установлено, что сложность и многогранность современных проблем требует формирования новых интегрированных систем менеджмента. Обосновано, что основными преимуществами применения интеграционного подхода над существующими является возможность рассмотрения объектов как сложных социоэкологоэкономических систем, а интегрированные системы менеджмента должны быть нацелены на оптимизацию взаимосвязанных экономических, социальных, технологических и природных процессов в единой среде. Предложено рассматривать интегрированную систему менеджмента как динамическую социально- и экологоориентированную модель регулирования общественного развития, направленную на реализацию принципов устойчивого развития, имплементированных в систему национальных и международных стандартов, конвенций, правил и рекомендаций ЕС, объединения усилий государственных органов власти, органов местного самоуправления, институтов гражданского общества, бизнеса.

Ключевые слова: евроинтеграционные процессы, интегрированные системы менеджмента, устойчивое развитие, международные стандарты.

Cherchyk Larysa, Dr. Sc. (Economics), Professor, Lesya Ukrainka Volyn National University, 


\section{INTEGRATED MANAGEMENT SYSTEMS AS A TOOL FOR DEEPENING EUROPEAN INTEGRATION PROCESSES}

Introduction. The application of modern management models, which include integrated management systems based on international standards, is one of the ways to integrate Ukraine into the European space, a relevant area of research. At the same time, the relevance of the formation of integrated management systems as a tool of European integration is determined by the need to ensure balanced, harmonious development, achieving positive stability, competitiveness and security.

The purpose of the article. The purpose of the study is to substantiate the theoretical and methodological foundations of the formation of integrated management systems.

Results. The existing approaches to the interpretation of the essence of integrated management systems are considered, the preconditions of formation, mission, purpose, principles, criteria of formation of integrated management systems are determined. It is established that the complexity and versatility of modern problems requires the formation of new integrated management systems. It is substantiated that the main advantages of applying the integration approach over the existing ones are the possibility of considering objects as complex socio-ecological economic systems, and integrated management systems should be aimed at optimizing interdependent economic, social, technological and natural processes in a single environment.

It is proposed to consider the integrated management system as a dynamic socially and ecologically oriented model of social development regulation aimed at implementing the principles and provisions of sustainable development implemented in the system of national and international standards, conventions, rules and recommendations by combining efforts of public authorities, local governments civil society, business.

Conclusions. Integrated management systems are a tool for implementing international standards and EU requirements to ensure an acceptable quality of the environment, living standards, human development, personal security and national security. This necessitates their application for micro-, meso-, macro-level objects, territorial communities, separate territorial systems, implementation in the system of public management and public administration while ensuring the integrity of the object of study and the object of managerial influence.

Key words: European integration processes, integrated management systems, sustainable development, international standards.

Постановка проблеми. Більшість сучасних соціально-економічних та екологічних викликів обумовлені кризою відносин у системі «суспільство - природа», наслідками якої є виснаження природних ресурсів, деградація екосистем, кліматичні зміни. Це безпосередньо погіршує якість життєвого середовища людей, визначає обмеження для економічної діяльності. Нераціональна система виробництва, націлена на нарощування обсягів товарів та послуг при мінімізації витрат, призводить до зниження їх якості, нехтування соціальною та природоохоронною складовими діяльності. Це негативно впливає на рівень та умови життя людей, їх здоров’я, можливості розвитку, формування інтелектуального, людського, природно-ресурсного та асиміляційного потенціалу, зумовлює деградацію екосистем, зниження конкурентоспроможності підприємств та економіки загалом. Політична нестабільність ускладнює процес прийняття та реалізацію стратегічних рішень, вироблення єдиного курсу еколого- та соціальноорієнтованого розвитку. Це обумовлює необхідність розробки нових підходів до формування стратегій розвитку на мікро-, мезо- та макрорівнях, які б передбачали підпорядкування економічних інтересів інтересам екологічної прийнятності та соціальної відповідальності, економічного розвитку, а не зростання. Складність та багатогранність зазначених проблем вимагає формування нових горизонтально та вертикально інтегрованих систем менеджменту на основі міжнародних стандартів. Оскільки Україна поставила за мету інтегруватися у Європейський Союз, є потреба в адаптації вище зазначених міжнародних підходів для застосування в Україні в системі корпоративного, регіонального, публічного менеджменту та державного управління.

Актуальність формування інтегрованих систем менеджменту (ICM) як інструменту трансформації державної соціально-економічної та екологічної політики, визначається необхідністю 
координації зусиль державних органів та місцевого самоврядування, керівників підприємств i організацій щодо постійних перетворень у системі суспільних відносин, економічній діяльності, екологічній сфері для забезпечення їх рівноважного, збалансованого, гармонійного розвитку, досягнення позитивної стабільності, конкурентоспроможності та безпеки.

Аналіз останніх досліджень і публікацій. Проблема формування ICM є актуальною і увага до неї зростає з боку як вітчизняних, так і зарубіжних науковців. Фундаторами теорії систем менеджменту якості стали Е. Демінг, К. Ісікава, Дж. Харрінгтон, А. Фейгенбаум. Вони сформували моделі управління якістю, на основі яких розробляються програми забезпечення якості продукції. Більшість останніх напрацювань зарубіжних науковців присвячені обгрунтуванню можливості інтегрованого управління якістю, довкіллям та безпекою в галузевих проектах, поєднуючи традиційні системи, пов'язані 3 міжнародними стандартами якості ISO 9001: 2015, довкілля ISO 14001: 2015, OHSAS 18001: 2007 з безпеки та гігієни праці та інших.

Саме поняття «інтегровані системи менеджменту» з'явилося у 90-х роках минулого століття у зв'язку з розробкою і одночасним функціонуванням кількох документованих систем менеджменту. Цей підхід був визнаний як найбільш ефективний спосіб удосконалення управління підприємством. Тому з появою нових стандартів на різні системи менеджменту активізувались процеси створення інтегрованих систем як частини загального менеджменту підприємств і організацій [1].

Зокрема, Дж.Г.Санц-Кальседо, А.Г. Гонсалес, О. Лопес, Д.Р. Салгадо, I. Камберо, Дж. М. Геррера [2] розробили інтегровану систему управління, яка приведе до стійких економічних вигод; Т. Нангес, Л. Мотта, О. Олівейра [3] дослідили еволюцію ICM та виявили відсутність досліджень у сфері мотивації безпеки, наявність труднощів впровадження стратегій 3 дотриманням стандартів. При цьому актуальними залишаються питання розробки нової концепції, що поєднуватиме усі елементи ICM з розвитком систем соціального й етичного менеджменту, менеджменту інформаційної безпеки, забезпечення їх практичної реалізації.

T. Холм, Т. Вуорісало, К. Саммалісто [4] показали застосування ICM для підвищення рівня освіти та забезпечення сталого розвитку в університетах. Розглянутий зарубіжний досвід доцільно використати для підвищення ефективності соціальної інфраструктури в Україні.

Важливість системи менеджменту інформаційної безпеки розглянуто у працях зарубіжних вчених $[5,6]$. Проте потребують удосконалення та подальшого розвитку новітні методології та дослідження для вимірювання й управління кіберзагрозами, забезпечення захисту інформації, ефективного управління бізнес-процесами та інформаційними ризиками.

Праці вітчизняних науковців [7-13] присвячені розгляду інтегрованих систем менеджменту на рівні підприємств різних видів економічної діяльності.

Виділення невирішених раніше частин загальної проблеми. Аналіз літературних джерел довів, що, не дивлячись на значні результати наукових досліджень у вище зазначених сферах, не знайшли відображення питання формування ICM мезо- та макрорівня. Потребують удосконалення підходи до формування ICM 3 урахуванням вимог інноваційного розвитку та забезпечення соціальної відповідальності бізнесу.

Мета і завдання дослідження. Метою дослідження є обгрунтування теоретико-методологічних основ формування інтегрованих систем менеджменту. Основними завданнями, на вирішення яких спрямоване дослідження є: визначення сутності ICM; визначення передумов формування ICM; розробка критеріїв та принципів формування ICM.

Викладення основного матеріалу та обгрунтування отриманих результатів дослідження. У процесі дослідження виявлено, що в теорії та практиці менеджменту організацій відбулось значне поширення інтегрованих підходів, зокрема процесного, системного, ситуаційного, функціонального. Запровадження ICM розглядається як передумова забезпечення фінансової стійкості та конкурентоспроможності, екологічно безпечного розвитку, підвищення інвестиційної привабливості підприємств. Проте акцент робиться на досягненні економічних цілей з урахуванням вимог до якості продукції, природоохоронних вимог, вимог до безпеки працівників.

На нашу думку, основними перевагами застосування інтеграційного підходу над існуючими $€$ можливість розгляду об’єктів як складних соціоекологоекономічних систем, а ICM мають бути 
націлені на оптимізацію взаємозалежних економічних, соціальних, технологічних і природних процесів в єдиному середовищі.

Теорія формування горизонтально та вертикально ICM як інструменту забезпечення прийнятного рівня якості довкілля, якості життя, людського розвитку, досягнення безпеки особистості та національної безпеки, на відміну від існуючих, передбачає його застосування для об'єктів різного рівня (мікро-, мезо-, макрорівня, територіальних громад, окремих територіальних систем), імплементацію в систему публічного менеджменту та державного управління при забезпеченні цілісності об'єкта дослідження та об'єкта управлінського впливу. Практично це формування нової парадигми розвитку в усіх його аспектах - світоглядному, екологічному, економічному, соціальному, суспільно-політичному, яка протиставляється сучасним викладкам економічної теорії, побудованої з відверто антропоцентричних, споживацьких поглядів і постулату задоволення зростаючих потреб людства, економічного зростання та макроекономічної рівноваги.

Концепція формування ICM передбачає визначення сутності, місії, мети, принципів і підходів до формування ICM.

Наразі вихідними положеннями при визначенні сутності ICM підприємств і організацій є: відповідність вимогам кількох міжнародних стандартів на системи менеджменту; потреба в об'єднанні процесів і процедур в одну структуру для ефективного управління підприємством; застосування системного і процесного підходів до управління підприємством; загальне управління ризиками $[1,7,10,11]$.

3 урахуванням зазначеного, традиційно інтегровану систему менеджменту розглядали як частину системи менеджменту організації, що відповідає вимогам кількох міжнародних стандартів на системи менеджменту і функціонує як єдине ціле [1, 7, 10-13].

Проте застосування моделі одночасного інтегрування змістило акценти на розробку систем менеджменту як сукупності взаємозалежних процесів з урахуванням інтересів, вимог та очікувань усіх зацікавлених сторін (задоволеність споживачів, якість та безпека навколишнього середовища, професійна безпека і здоров'я, задоволеність працівників, соціальної відповідальності підприємств, фінансові результати, етичні підходи до суспільства і до свого персоналу) $[10,12,13]$.

В межах базових концепцій визначено принципи формування ICM:

- концепція загального управління якістю (TQM), основними принципами якої є орієнтація на споживача, лідерство керівника, залучення працівників, процесний підхід в діяльності, системний підхід до менеджменту, постійне поліпшення, прийняття рішень, заснованих на фактах, взаємовигідні відносини з постачальниками [12, с. 32];

- концепції досконалості, в основі яких лежать принципи досягнення збалансованих результатів; створення доданої цінності для споживачів; лідерство; управління через процеси; персонал як основа успіху; підтримка креативності та інновацій; партнерство; відповідальність за майбутнє [13, 14];

- логіка RADAR як сукупності вимог за такими складовими як результати, досягнення яких заплановано в контексті обраної стратегії; планування та розробка комплексу підходів для досягнення необхідних результатів в поточному та перспективному періодах; розгортання підходів на системній основі для ефективного впровадження; оцінка та перегляд використовуваних підходів на основі моніторингу та аналізу досягнутих результатів, а також інформації, одержуваної в процесі освоєння нових знань $[13,14]$.

Для уточнення сутності ICM та інших аспектів дослідження ми керуватимемось такими базовими положеннями.

1. Інтегральним показником та критерієм формування будь-яких систем менеджменту на будьякому рівні є безпека. Управлінські рішення повинні прийматись на засадах підпорядкування комерційних інтересів інтересам екологічної прийнятності та соціальної відповідальності, що передбачає виробництво не лише суспільно корисних товарів та послуг з використанням екологічно чистих технологій, а й забезпечення матеріального достатку для подолання бідності, добробуту, забезпечення комфорту та захищеності людей, що можливе при впровадженні горизонтально та вертикально ICM.

2. Системну безпеку та відчуття захищеності визначає середовище проживання людей, яке формують природно-географічні, політичні, історико-культурні, суспільні та економічні чинники, поєднання яких забезпечує або унеможливлює суспільний розвиток загалом, економічний зокрема. 
Це обумовлює необхідність чіткого визначення пріоритетів при розробці національної, регіональних, місцевих стратегій розвитку, прийнятті урядових, регіональних, підприємницьких рішень, в основу яких необхідно закладати критерії захисту національних інтересів, якості довкілля, якості життя, людського розвитку, конкурентоспроможності економічних систем, тобто критеріїв ICM.

3. Економічна система є складовою соціальної, іiі забезпечувальною підсистемою, соціальна система формується та розвивається в межах природної, екологічна система $є$ середовищем життєдіяльності людей, значною мірою визначає якість життя людей, є середовищем економічної діяльності. Тому, оскільки існує тісний взаємозв' язок та взаємозалежність існування/функціонування та розвитку кожної з них, системна безпека досягається лише завдяки врахуванню чинників забезпечення безпеки кожної на засадах узгодження інтересів та застосування як горизонтально так i вертикально ICM.

3 урахуванням зазначеного, на нашу думку, ICM $\epsilon$ динамічною соціально- та екологоорієнтованою моделлю регулювання суспільного розвитку, спрямованою на реалізацію принципів сталого розвитку, імплементованих у систему національних і міжнародних стандартів, конвенцій, правил та рекомендацій шляхом поєднання зусиль державних органів влади, органів місцевого самоврядування, інститутів громадянського суспільства, бізнесу.

Виходячи з цього, місія ICM - комплексне вирішення проблем на кожному рівні, забезпечення прийнятного рівня та якості життя, якості навколишнього середовища і життєдіяльності, рівня людського розвитку в умовах природно-ресурсних та екологічних обмежень.

Мета впровадження ICM - забезпечення конкурентоспроможності вітчизняних підприємств та національної економіки, припинення деградації екосистем, забезпечення високого рівня та якості життя громадян, їх захищеності, виконання міжнародних зобов'язань України та ії інтеграцію у світовий простір як повноцінного партнера, захист національних інтересів у процесі глобалізації.

Методологічний інструментарій формування ICM передбачає розробку принципів, критеріїв, обгрунтування нових підходів, які, на відміну від існуючих, повинні розглядати об'єкти управління як соціоекологоекономічні системи та враховувати усі аспекти їх функціонування.

При формуванні ICM доцільне поєднання таких підходів: системно-структурного - для розробки моделей ICM; процесного - для розробки механізмів формування ICM; інституційного та функціонального - для обгрунтування змістовного наповнення ICM різного рівня; ієрархічного - для розробки та впровадження вертикально та горизонтально ICM.

Безпека $є$ інтегральним показником та критерієм формування систем менеджменту на різних рівнях. Тому управлінські рішення повинні прийматись на засадах підпорядкування комерційних інтересів інтересам екологічної прийнятності та соціальної відповідальності. Це обумовлює необхідність чіткого визначення пріоритетів при розробці національної, регіональних, місцевих стратегій розвитку, прийнятті урядових, регіональних, підприємницьких рішень, в основу яких необхідно закладати критерії якості довкілля, якості життя, людського розвитку, конкурентоспроможності економічних систем.

Критеріями формування та ефективності функціонування ICM, на відміну від означених в джерелах [1-9], ми розглядаємо якість життя, якість навколишнього середовища, рівень людського розвитку, безпеку життєдіяльності; рівень екологічної свідомості та відповідальність громадян; екологічність виробництва; рівень самовідновлюваних властивостей та асиміляційного потенціалу біосфери.

Зокрема, процесний підхід до формування ICM підприємств розглядається як сукупність послідовних взаємопов'язаних етапів управлінської діяльності, які забезпечують обгрунтування, прийняття та реалізацію управлінських рішень щодо досягнення екологічно безпечного, соціально відповідального та економічно ефективного стратегічного розвитку підприємства.

При застосуванні процесного підхіду до формування ICM для територіальних систем за критерієм якості навколишнього середовища передбачаються такі процеси: законодавче забезпечення; формування нормативної бази, процедур, правил; організаційне забезпечення; моніторинг і діагностика стану НC; екологоорієнтоване стратегічне планування; вибір стратегії забезпечення якості НС та організація ії реалізації; контроль; регулювання; оцінка ефективності.

Синтетичний підхід до формування ICM національного рівня дозволяє розглядати їх сукупність інституцій, принципів, важелів, методів та інструментів впливу, націлених на оптимізацію відносин 
у системі «суспільство - природа» щодо забезпечення безпеки всіх сфер життєдіяльності за умов збереження цілісності, функціонування в межах самовідтворення, охорони довкілля, задоволення суспільних потреб, відновлення та збереження здоров'я, розвитку економіки на прийнятному рівні прибутковості, у межах екологічно допустимих норм та соціальної відповідальності бізнесу.

Висновки та перспективи подальших досліджень. У процесі дослідження виявлено, що в теорії та практиці менеджменту організацій відбулось значне поширення інтегрованих підходів та формування інтегрованих систем менеджменту як таких, що відповідають вимогам кількох міжнародних стандартів. Впровадження ICM визнано найбільш ефективним способом удосконалення системи менеджменту підприємством.

Встановлено, що складність та багатогранність сучасних проблем вимагає формування нових інтегрованих систем менеджменту. Обгрунтовано, що основними перевагами застосування інтеграційного підходу над існуючими $€$ можливість розгляду об'єктів як складних соціоекологоекономічних систем.

Базові положення, сформульовані автором, обумовлюють визначення ICM як динамічної соціально- та екологоорієнтованої моделі регулювання суспільного розвитку, спрямованої на реалізацію принципів сталого розвитку, імплементованих у систему національних і міжнародних стандартів, конвенцій, правил та рекомендацій шляхом поєднання зусиль державних органів влади, органів місцевого самоврядування, інститутів громадянського суспільства, бізнесу.

Авторська позиція полягає у використанні ICM як інструменту забезпечення прийнятного рівня якості довкілля, якості життя, людського розвитку, досягнення безпеки особистості та національної безпеки, передбачає застосування ICM для об'єктів різного рівня (мікро-, мезо-, макрорівня, територіальних громад, окремих територіальних систем), імплементацію в систему публічного менеджменту та державного управління при забезпеченні цілісності об'єкта дослідження та об'єкта управлінського впливу.

Водночас, отримані результати мають слугувати основою для обгрунтування та прийняття управлінських рішень керівниками підприємств, органами місцевого самоврядування та держави щодо впровадження ICM відповідного рівня.

\section{Джерела та література}

1. Корешков В., Нахаренко В., Кусакін М., Осмола І. Інтегро́вані системи менеджменту організації. Особливості, проблеми і шляхи вирішення. Стандартизаиія. Сертифікаиія. Якість. № 1 (44). 2007. С. 54-61.

2. J.G.Sanz-Calcedo, A.G.González, O.López, D.R.Salgado, I.Cambero, J.M.Herrera. Analysis on Integrated Management of the Quality, Environment and Safety on the Industrial Projects. Procedia Engineering. V.132, 2015, p 140-145.

3. T.V. Nunhes, L. Motta, OJ de Oliveira. Evolution of integrated management systems research on the Journal of Cleaner Production: Identification of contributions and gaps in the literature. Journal of Cleaner Production. V.139, 2016, p. 1234-1244.

4. T. Holm, T. Vuorisalo, K. Sammalisto. Integrated management systems for enhancing education for sustainable development in universities: a memetic approach. Journal of Cleaner Production. V.106, 2015, p. 155-163.

5. Thomas R. Peltier. Information Security Policies, Procedures, and Standards: guidelines for effective information security management. 1st Edition. CRC Press, Inc. Boca Raton, FL, USA, 2016, p. 286.

6. ZA. Soomro, MH. Shah, J. Ahmed. Information security management needs more holistic approach: A literature review. International Journal of Information Management. V. 36, 2016, p. 215-225.

7. Буряк Р. І. Інтегрована система менеджменту як основа забезпечення сталого розвитку підприємства аграрного сектору України. Вісник Академії прайі і соиіальних відносин Федераџіï профсспілок України. 2015. № 3-4. C. 36-44.

8. Криворучко, О. М. Інтегрований підхід до удосконалення бізнес-процесів підприємства. Економіка трансп. комплексу. 2018. Вип. 32. С. 17-29

9. Тельнов А.С., Решміділова С.Л. Тенденції та суперечності розбудови інтегрованих систем управління якістю. Вісник Хмельницького наиіонального університету. 2014. № 5 . T. 2. C. $149-155$.

10. Інтегровані системи управління якістю на молокопереробних підприємствах (CEM + HACCP). URL: https://pidruchniki.com/75384/tovaroznavstvo/integrovani_sistemi_upravlinnya_ yakistyu_molokopererobnih_pidpri yemstvah_nassr (10.02.2021). 
11. Момот А.И., Мартынюк Е.С. Недостатки и проблемы функционирования систем менеджмента на предприятиях. Theoretical and Practical Aspects of Economics and Intellectual Property. 2013. Issue 1, Volume 2. P. 24-28.

12. Разработка интегрированных систем управления на базе международных стандартов: методологические основы : монография / Мортеза Раджаб Заде, В. А. Залога, А. В. Ивченко. Сумы : Сумский государственный университет, 2018. 114 с.

13. Новожилова С.В., Вишневська А.С., Новожилова Л.О. Впровадження інтегрованих систем управління на молокопереробних підприємствах (СЕМ + НАССР). Продукты \& ингредиенты. 2011. № 3. С.56-57.

14. Левина Т.А. Формирование системы менеджмента качества в интегрированной корпоративной структуре. Диссертация на соискание ученой степени кандидата экономических наук. Специальность 08.00 .05 - Экономика и управление народным хозяйством. Саранск : 2017. 220 с.

\section{References}

1. Koreshkov V., Nakharenko V., Kusakin M., Osmola I. (2007). Intehróvani systemy menedzhmentu orhanizatsii. Osoblyvosti, problemy i shliakhy vyrishennia [Integrated management systems of the organization. Features, problems and solutions.]. Standartyzatsiia. Sertyfikatsiia. Yakist - Standardization. Certification. Quality. 1 (44). 54-61 [in Ukrainian].

2. J.G.Sanz-Calcedo, A.G.González, O.López, D.R.Salgado, I.Cambero, J.M.Herrera. (2015). Analysis on Integrated Management of the Quality, Environment and Safety on the Industrial Projects. Procedia Engineering. 132. $140-145$.

3. T.V. Nunhes, L. Motta, OJ de Oliveira. (2016). Evolution of integrated management systems research on the Journal of Cleaner Production: Identification of contributions and gaps in the literature. Journal of Cleaner Production. 139. 1234-1244.

4. T. Holm, T. Vuorisalo, K. Sammalisto. (2015). Integrated management systems for enhancing education for sustainable development in universities: a memetic approach. Journal of Cleaner Production. 106. 155-163.

5. Thomas R. Peltier. (2016). Information Security Policies, Procedures, and Standards: guidelines for effective information security management. 1st Edition. CRC Press, Inc. Boca Raton, FL, USA. 286.

6. ZA. Soomro, MH. Shah, J. Ahmed. (2016). Information security management needs more holistic approach: A literature review. International Journal of Information Management. 36. 215-225.

7. Buriak R. I. (2015). Intehrovana systema menedzhmentu yak osnova zabezpechennia staloho rozvytku pidpryiemstva ahrarnoho sektoru Ukrainy [Integrated management system as a basis for sustainable development of the agricultural sector of Ukraine]. Visnyk Akademii pratsi $i$ sotsialnykh vidnosyn Federatsii profspilok Ukrainy - Bulletin of the Academy of Labor and Social Relations of the Federation of Trade Unions of Ukraine. 3-4. 36-44 [in Ukrainian].

8. Kryvoruchko, O. M. (2018). Intehrovanyi pidkhid do udoskonalennia biznes-protsesiv pidpryiemstva [An integrated approach to improving the business processes of the enterprise]. Ekonomika transp. Kompleksu - Economics of transp. complex. 32. 17-29 [in Ukrainian].

9. Telnov A.S., Reshmidilova S.L. (2014). Tendentsii ta superechnosti rozbudovy intehrovanykh system upravlinnia yakistiu [Trends and contradictions in the development of integrated quality management systems]. Visnyk Khmelnytskoho natsionalnoho universytetu - Bulletin of Khmelnytsky National University. 5. 149-155 [in Ukrainian].

10. Intehrovani systemy upravlinnia yakistiu na molokopererobnykh pidpryiemstvakh (SEM + NASSR). [Integrated quality management systems at dairy enterprises (CEM + HACCP)]. URL: https://pidruchniki.com/75384/tovaroznavstvo/integrovani_sistemi_upravlinnya_yakistyu_molokopererobnih_pidpri yemstvah_nassr [in Ukrainian]. (10.02.2021).

11. Momot A.Y., Martыniuk E.S. (2013). Nedostatky y problemы funktsyonyrovanyia system menedzhmenta na predpryiatyiakh [Disadvantages and problems of functioning of management systems at the enterprises]. Theoretical and Practical Aspects of Economics and Intellectual Property - Theoretical and Practical Aspects of Economics and Intellectual Property. Issue 1, Volume 2. 24-28. [in Russian].

12. Morteza Radzhab Zade, V. A. Zaloha, A. V. Yvchenko. (2018). Razrabotka yntehryrovannыkh system upravlenyia na baze mezhdunarodnыkh standartov: metodolohycheskye osnovы [Development of integrated control systems based on international standards: methodological foundations]. Sumb: Sumskyi hosudarstvennыi unyversytet [in Russian].

13. Novozhylova Ye.V., Vyshnevska A.S., Novozhylova L.O. (2011). Vprovadzhennia intehrovanykh system upravlinnia na molokopererobnykh pidpryiemstvakh (SEM + NASSR) [Introduction of integrated management systems at dairy enterprises (SEM + HACCP)]. Produktbl \& ynhredyentbl - Products \& Ingredients. 3. 56-57 [in Ukrainian].

14. Levyna T.A. (2017). Formyrovanye systemы menedzhmenta kachestva v yntehryrovannoi korporatyvnoi strukture [Formation of a quality management system in an integrated corporate structure]. Saransk [in Russian]. 